\title{
Article
}

\section{Angels with Dirty Faces \\ Gosha Rubchinskiy and the Politics of Style}

\author{
Graham H. Roberts \\ Université Paris Nanterre
}

\begin{abstract}
In many ways, twenty-first century Russia is the land par excellence of extreme masculinity. President Putin himself regularly indulges in spectacular performances of extreme masculinity, whether it be pledging to 'bump off' Chechen terrorists in their 'shithouses', swimming in ice-cold Siberian lakes, or posing in the pilot's seat of a supersonic strategic bomber. Men's fashion and fashion imagery is one of the rare areas of Russian culture where the kind of masculinity embodied (in a literal sense) by Putin is still challenged, and indeed subverted. Perhaps the most interesting Russian men's fashion designer working today, certainly the designer who has engaged most persistently with political change, is Gosha Rubchinskiy. In his work he foregrounds various 'extreme' forms of Russian masculinity, from the angelic youth at one end of the spectrum through the brown-shirted neo-fascist adolescent, to the shavenheaded football fan at the other end. He does so, he maintains, in order to change the way Russia is perceived in the world. Indeed, if Dostoevsky once claimed that 'beauty will save the world,' Rubchinskiy self-consciously enlists what he refers to as the 'beauty' of his models in an attempt to challenge the negative image of Russia generated by western media as part of what he has called an 'informational [sic] war' against his native country. Borrowing concepts from Bakhtin (the chronotope, carnival) and Foucault (heterotopia), I examine Rubchinskiy's extreme masculinities, and the questions they raise about masculinity, about the cultural relationship between Russia and the West, fashion as a discrete cultural practice, and the place and role of the fashion designer in society.
\end{abstract}

Keywords fashion, Gosha Rubchinskiy, masculinity, Russia, visual representation

'Angels with dirty faces, Angels from nowhere places, Kids like me and you' Sham 69, Angels with Dirty Faces

In many respects, post-soviet Russia is the ultimate land of extreme masculinity. The secret initiation rites, violent 'protection' methods and brutal moral codes of the mafia that spread through the country in the 1990s, for example, and indeed of the loose network of criminal fraternities that preceded it, known as the 'thieves-in-the-law' (vory$v$-zakone), have been well documented (Varese 2001). The countless examples of Russian male public figures engaging in extreme forms of behaviour include the outlandish farright nationalist politician and one-time presidential candidate Vladimir Zhirinovsky, whose 1998 book The ABC of Sex (Azbuka seksa) called for Russia to model itself on Thailand and place sex at the centre of its economy (Sperling 2015, 65), and Alexander Zaldostanov alias 'The Surgeon', free-wheeling leader of the infamous Night Wolves motorcycle club and personal friend of President Putin, who publicly decorated him in 2013 with the Russian Order of Honour for encouraging patriotic feelings in the 
country's youth. Putin himself regularly indulges in spectacular performances of extreme masculinity, whether it be pledging to 'bump off' Chechen terrorists in their 'shithouses' (Gorham 2013), swimming in ice-cold Siberian lakes, or posing in the pilot's seat of a supersonic strategic bomber (on Putin as 'strongman,' see also Roxburgh 2012). Indeed, by uniting in one and the same body the three cultural paradigms that have historically codified heroic masculinity - the warrior, the philosopher and the ruler (Goscilo 2013) - Putin has made a quite extreme form of hegemonic, heteronormative (and indeed homophobic) masculinity a central pillar of Russian national identity (see also Sperling 2015).

As Putin's performances underline, and as Goscilo (2013), Healey (2010) and others have shown, masculinity is increasingly central to contemporary debates about Russian identity. This should not surprise us. For much of Russian history, as Evans Clements (2002) has argued, the question of Russian identity has been primarily clothed in debates about Russian men and their bodies, how they should behave, what they should look like, and how they should be dressed (on the symbolic significance of the body, and especially the male body, in the Soviet era, see also Kon 2003, and Amico 2014). As she puts it

What is certain ... is the centrality of conceptions of the masculine in Russia's past. Tsarist bureaucrats, Stalinist economic planners, intellectuals and social reformers from the eighteenth to the twentieth century understood that they could not change Russia unless and until they changed Russian men. Fundamental to this task was defining what Russian men were and what they should become (Evans Clemens 2002, 12).

As I have noted elsewhere, men's fashion and fashion imagery is one of those areas of Russian culture where notions of 'what Russian men [are] and what they should become' (Roberts 2017a) are still in a state of flux. Moreover, it is one of the relatively rare domains where the kind of hegemonic masculinity embodied (both in a metaphorical, and in a literal sense) by Putin, while sometimes found, is also frequently challenged, not to say subverted. Men's fashion designer Serguei Teplov, for example, has used androgynous-looking male models in his publicity material, while some of Cyrille Gassiline's shoots have a distinctly homoerotic feel about them. Designers such as these bear out Karaminas' point that 'fashion imagery, as a mode of representation, is in constant flux with the social forces that shape culture and political change' (Karaminas 2012, 180).

The question of political change in general, and of the relationship between representation, masculinity and power in particular, is especially relevant to Russia, a country where traditional gender stereotypes - and in particular the equation of masculinity with such characteristics as physical strength, high economic status, and emotional restraint - are especially popular among the country's young male population (Levant et al. 2003). Perhaps the most interesting men's fashion designer working in Russia today, certainly the designer who has engaged most persistently in his 'fashionscapes' (Karaminas 2012) with the forces of social and political change, is Comme des Garçons' Gosha Rubchinskiy (Roberts 2017b). In what follows, I propose to examine Rubchinskiy's work, and the different forms of extreme masculinity that appear 
therein. In doing so, I shall explore the questions Rubchinskiy raises not just about masculinity, but also about Russia itself, the cultural relationship between Russia and the West, fashion as a discrete cultural practice, and the place and role of the fashion designer in society.

\section{Gosha Rubchinskiy, the Image Maker}

Politics, style and extreme masculinity run through all of Rubchinskiy's work like an inextricable tripartite red thread. That work itself is remarkably diverse for such a relatively short (if nevertheless meteoric) career, although Rubchinskiy has been keen to emphasize the ways in which his different creative activities complement each other (ICA 2014). A graduate of the Moscow State University of Design and Technology, he first made his name as a fashion photographer and designer of street wear in Moscow in 2008. Empire of Evil, the title of his first men's fashion collection, presented at the end of that year, can be seen both as an allusion to Ronald Reagan's description of the USSR, and as a nod towards the anti-Russian sentiment felt in much of the West following the country's brief war that summer with neighbouring Georgia (for a short extract of this show, see YouTube 2008). His second collection was shown in a disused Orthodox church-turned-gym, while his third, entitled The Sunrise Is Not Far Behind the Mountains consisted of a video shot in St. Petersburg, a book of photographs, and the collection itself (ICA 2014). In 2012, Rubchinskiy was signed up by Adrian Joffe at Comme des Garçons (Kansara and Fedorova 2016). Since then, while keen to stress his independence (YouTube 2015), he has effectively operated as a (highly bankable) subbrand for Joffe, producing what one fashion journalist has succinctly described as 'the new black' (Massoca 2016; on Rubchinskiy as 'the hottest designer in menswear' see also Ferrier 2016). Perhaps the high point of his career so far came in June 2016, when he was invited to present his Spring/Summer 2017 collection as guest designer at Florence's biannual Pitti Uomo, currently the world's largest menswear trade fair (Leitch 2017), and also one of the most prestigious.

Rubchinskiy's guest designer status at the Pitti Uomo, and more generally his success with critics and consumers alike (see for example Stoppard 2015), is all the more remarkable, given that the man himself appears not to wish to be seen as a fashion designer. As he put it in an interview with SHOWstudio's Lou Stoppard in 2015: 'I still don't think I'm a fashion designer. I feel more comfortable when someone says, "You're an artist, or photographer, or producer" (YouTube 2015). In another interview, this time given to $i$-D's Anders Christian Madsen on the fringe of his Autumn/Winter 2017-18 runway show presented in the Russian enclave of Kaliningrad in January 2017, Rubchinskiy claimed to be first and foremost an 'image maker' (Madsen 2017a). His images are designed, he maintained in that same interview, in order to change the way Russia is perceived in the world. Indeed, if Dostoevsky once claimed that 'beauty will save the world,' Rubchinskiy self-consciously enlists what he refers to as the 'beauty' of his models in an attempt to challenge the negative image of Russia generated by western media as part of what he has called an 'informational [sic] war' against his native country (YouTube 2015).

Showing us his 'world' (Suliman 2015), and the youths who make up that world, would appear then to be just as, if not more, important to Rubchinskiy as designing t-shirts. 
Discussing his 2008 Empire of Evil show, he has suggested: 'I wanted it to be like a performance. It was not about the collection, but about these boys, this generation, this energy' (quoted in Kansara and Fedorova 2016). Indeed, fashion may be little more than the means to an end for Rubchinskiy, a way for him to stage performances - and specifically performances of masculinity - around the images he creates. Even Adrian Joffe, who has been distributing Rubchinskiy's designs since 2009, sees him less 'as a fashion designer,' than as 'a recorder of things' (Kansara and Fedorova 2016). Rubchinskiy's interest in visually recording not just any 'things,' but the quite specific, and at times extreme, masculinity of teenage boys in particular may be why in 2016 he helped design the Mad About The Boy exhibition, curated by Lou Stoppard at SHOWstudio, a fashion film website. This exhibition, as Stoppard herself has put it, 'explored fashion obsession with youth, focusing on the way ideas of the teen boy are constructed through specific collections and images' (SHOW studio [n. d.]).

Rubchinskiy himself has directed two films documenting the activities of teenage boys in his native Russia, both of which can be found on his official website (Rubchinskiy [n. d. a]). These are Transfiguration and The Casting of Alexey (both released in 2012). This is also the subject of three of his collections of photographs: Transfiguration (2012), published to coincide with the release of the eponymous video, Crimea / Kids (2014) and Touth Hotel (2015), all strictly limited editions produced and sold exclusively by Dover Street Market's IDEA books. In 2016, Rubchinskiy published a fourth collection of photographs in which young men - at times fully clothed, at others semi-naked or completely undressed - feature prominently, namely The Day of My Death. This book was issued to coincide with the eponymous 17-minute video directed by Russian filmmaker Renata Litvinova and designed by Lotta Volkova, screened at the end of Rubchinskiy's Pitti Uomo show.

This last example, and in particular the involvement of Volkova, hailed recently as 'the coolest woman in the world,' and 'fashion's most in-demand creative' (Fox 2016), reminds us that whatever the man himself may say about his work, Rubchinskiy's international reputation undeniably rests primarily on his fashion designs. These designs have gained a good deal of (very positive) critical attention in recent years. An article on 'Goshattitude' in the Spring/Summer 2017 edition of Vogue Hommes went so far as to claim that 'if you're into fashion and you haven't heard of Gosha Rubchinskiy, then there's something wrong [with you]' (Anon. 2017; our translation). Commenting on the disruptive mise-en-scène of Rubchinskiy's Spring/Summer 2016 show in Paris, SHOWstudio's Stoppard commented: 'Rubchinskiy's clothes merit consideration, they demand that you reflect and ponder. Unlike a lot in fashion at the moment, they're worth waiting for' (Stoppard 2015). Stoppard's observation nevertheless has relevance not just for Rubchinskiy's collections, and the runway shows at which those collections are displayed, but also for his camera work, his photography collections and his video output. Taken collectively, Rubchinskiy's work presents us with a whole range of extreme masculinities, as we shall now see.

\section{Rubchinskiy's Videos - Angels and Demons}

When asked about the relationship between his different activities in an interview at London's Institute of Contemporary Arts in 2014, Rubchinskiy himself commented that 
it was very difficult for him to separate film, fashion, and photography, and suggested (a little enigmatically) that designing clothes was in a sense complementary to, and a continuation of the exchanges he had with the young people he associated with and who appeared in his films (ICA 2014). One of the best places to look to see just the kind of young people Rubchinskiy likes to associate with, and the kind of exchange he has with them, is his 2012 video Transfiguration. This was produced while he was taking a year out from designing clothes, due to the fact that, as Rubchinskiy put it in the interview at London's ICA (an interview which coincided with a public screening of the film), it is so difficult to work as a fashion designer in contemporary Russia (ICA 2014). The film's central trope - skateboarding - is nevertheless closely connected to Rubchinskiy's activity as a designer; Rubchinskiy's early shows presented his adaptations of the clothes worn by his skateboarding friends (Fury 2016).

The focus of this 45-minute documentary film is the vibrant youth skateboarding culture in the New Holland area of Russia's second city, St. Petersburg. While politically, this might appear to be a perfectly innocent subject, this is certainly not how Rubchinskiy himself sees it. As he put it in an interview with AnOther magazine: 'I filmed Transfiguration before the crisis with Ukraine [following Russia's annexation of the Crimean peninsula in 2014], but revising [sic] the work it becomes relevant now. It is my best possible comment on politics as an artist. Russians skate on tanks but they also skate on skateboards - they're not all bad!' (Baker 2014). From the outset, this project was designed to change the way both St. Petersburg, and Russia itself, are perceived in the West. Russia is meant to be seen not as an Empire of Evil, but simply as a place where young lads hang out, listening to rock music, playing in the street or lazing on the beach just like anywhere else in the world. Indeed, the young men Rubchinskiy filmed (female skateboarders are conspicuous by their absence here), and the kind of masculinity they embodied, were central to this project. To quote from the same interview: 'I wanted the film to be part of an effort to rebuild Saint Petersburg creatively, and to make it a more prominent part of the cultural state of Russia. I spent two months in New Holland, where the boys were coming and going to skate. They were authentic, beautiful boys' (Baker 2014).

For the most part the film contains various scenes of skateboarders in and around St. Petersburg, together with interviews of some of the skaters, and scenes from rock concerts, including two that actually take place in a skate park. The film's only (vaguely) narrative thread relates to an unnamed young boy aged about 14 or 15 . Identified by Rubchinskiy in a subsequent interview as Maxim (Baker 2014), this boy appears in a number of scenes, repairing his skateboard, talking about his love for the sport, practising his art (with varying degrees of proficiency) in the city's skate parks, and discussing his dreams for the future (at one point he says he wants to open his own skateboard shop, or possibly become a fashion designer, since this seems to be an easy way to make money).

What Rubchinskiy himself describes (Baker 2014) as the authenticity, and indeed the beauty of the boys we see in Transfiguration is in sharp contrast to the sombre, selfconscious performativity of many of the male models in some of his earlier runway shows. Indeed, there is something distinctly, almost radiantly angelic about Maxim, with his youthful innocence and disarming spontaneity, and his tight blond locks and clear 
green eyes atop a smoothly pre-pubescent and frequently exposed torso. One could argue, however, that the most angelic character in this video is not Maxim, but rather a slightly older, unnamed boy who appears with him in one particular scene. In many respects this boy is very different from Maxim, who derides him for spending his time with his head in books. Asked what he is currently reading by the interviewer (Rubchinskiy himself), he holds up a copy of The Devils, Dostoevsky's novel about a group of revolutionary students in imperial St. Petersburg. While Rubchinskiy has claimed that Transfiguration was completely unscripted, the allusion to The Devils can be seen as a thinly veiled reference to one particular kind of 'transfiguration,' namely the radical social, political, economic and cultural change Russia has been undergoing since the 1990s, the decade in which Rubchinskiy himself grew up - an important theme for Rubchinskiy both in his fashion designs and in his photography (Cadogan 2017). Indeed, this boy himself alludes to this theme, in a subsequent scene in which he appears alone, discussing how people are generally afraid of change, and find it so difficult to adapt to new situations. But he is no revolutionary 'devil' - quite the opposite. Like Maxim, he has something distinctly angelic about him. This quality comes across not just in his blond hair, his piercing grey-green eyes, and his white t-shirt, but also in the way this particular scene is filmed: he is shot in mid-distance and in ethereal monochrome, and bathed in bright sunshine as he stands against a plain white background; the ethereal, luminously other-worldly aspect of the image is reinforced by bleaching, slight blurring and even over-exposure; and his words become increasingly indistinct and indeed incomprehensible, as the intradiegetic soundtrack is gradually replaced by Bach's The Well-Tempered Clavier (Figure 1).

Fig. 1. The angel of Transfiguration (source: Rubchinskiy [n. d. a]) 

and in the accompanying book. For example, the photograph of the youth with angel's wings tattooed across his back is placed directly opposite a photograph of the top of a Russian Orthodox church, featuring an angel carrying a cross. Most often, however, Rubchinskiy uses not angels, but other models of classical beauty. On one occasion, his film switches suddenly from a skateboarder to the still image of a portrait of a youth by Italian Renaissance artist Botticelli. Their matching hairstyles, and the close similarities in terms of framing and composition serve to reinforce the association between these two male subjects (Figures 3a and 3b, below). The film includes stills of other Botticelli portraits, as well as images of paintings by Leonardo da Vinci (such as his Madonna Litta, c. 1490). A close-up of the latter, featuring the baby Jesus suckling on his mother's breast, can be found in the Transfiguration book, directly opposite a photograph of three young, anonymous skaters, shot from behind sitting on their boards, gazing out across the tarmac. At another moment, Rubchinskiy's camera lingers over a series of classical sculptures, including Michelangelo's The Dying Captive (c. 1513) from the Louvre in Paris. A still photograph of this particular statue is also featured in the Transfiguration book, juxtaposed with a monochrome image of a young skateboarder in a similar pose, pulling on a t-shirt on which one can read the name of the US rock band the Ramones. In what can be seen as an example of Rubchinskiy's homoerotic aesthetic (Roberts 2017a), at two distinct moments in the book Rubchinskiy juxtaposes the photograph of a painting of the gay icon Saint Sebastian with images of young St. Petersburgers. 
himself has put it in a different context (his Autumn/Winter 2017 show held in the Russian enclave of Kaliningrad in January 2017, which featured a collaboration with German sportswear brand Adidas): 'Now things are changing, you see skate kids wearing football clothes and you can see football fans wearing skate stuff. Cultures mix, subcultures mix' (quoted in Fearon 2017, emphasis mine).

Conflating what French art historian Régis Debray (1992) identifies as the three historical stages of the image (what he calls 'the three ages of the gaze'), namely the locally rooted idol, Western figurative art and global visual culture, Rubchinskiy also of course invites us to view him himself as a new Botticelli or da Vinci. This is particularly audacious, when one considers that the male subjects he depicts are purportedly chosen 'spontaneously.' This is especially the case with his photo shoots and runway shows, where Rubchinskiy is notorious for finding his models on social media (as for example the models for his Pitti Uomo show: Muret 2016). The Transfiguration book features photographs of one of these models, taken during a photo shoot which, rather curiously, had nothing at all to do with the eponymous video. The model in question is the subject of the second of the two videos on Rubchinskiy's official website, namely the ten-minute long Casting of Alexey. This film shows us a series of interviews with Alexey, as well as a photo shoot, and extracts from one of his social media accounts. However, Alexey presents a very different kind of extreme masculinity from that embodied by Maxim and his skateboarding pals. In the first half of the film he is a nervous, self-conscious and rather pallid youth. In the second half, on the other hand, he appears extremely cynical, consciously exploiting other people for his own advantage. In the on-line social media sequence he is remarkably sexually aggressive, using extremely crude language and at one point even sending a girl a photograph of a dildo, the image of which fills the screen.

As I have argued elsewhere (Roberts 2017b), Rubchinskiy may be said to "carnivalize" (Bakhtin 1968) the catwalk here. This is because he takes us behind the scenes, both of his own work as a fashion photographer, and of Alexey's private life, breaking down boundaries in a way which not only introduces a crudely bawdy element, but also turns upside down our expectations as viewer and our understanding of what a "casting" is, However, the essential point about carnival is that it offers merely a simulacrum of liberatory licentiousness; its ultimate purpose is to reassert authority and control. 'Taking back control and showing [the audience] what I want them to see' is the reason designer Gareth Pugh makes fashion films (quoted in Khan 2012, 253). While one could argue that the point of Rubchinskiy's carnival here is to allow him, like Pugh, to take back control over his brand, there is arguably something else behind Alexey's display of extreme masculinity, too. To see what exactly that might be, we need to turn from his films to his runway shows. For Rubchinskiy himself has said that his films and photographs convey the same 'message' which is there in his clothes, but which is not necessarily quite so clear (ICA 2014). So what about those clothes? And what about the Russian youths who model them, and whose images (unlike Alexey's) can be found in countless fashion publications, both off- and online, around the world? 


\section{Rubchinskiy's Runway Shows}

The Casting of Alexey is noteworthy for two things in particular. First, by the way Alexey offers his body for consumption (by Rubchinskiy, by his social media fans, and ultimately by us, the viewer), it reminds us that the body is the cornerstone of social identity construction (Belk 1988). Second, it underlines the fact that this construction is primarily negotiated in space (Roux 2014), even when the space in question is the hyperspace of social media (Bauman 2007). As for social media, that particular space emerges in The Casting of Alexey as a quintessentially carnivalesque milieu. In many ways, it is a topsyturvy world where the normal order of things is reversed, albeit temporarily, and there are, it would seem, no limits on what the imagination can come up with (Bakhtin 1968, 9; see also Maclaran and Brown 2005, 312). This makes it a utopian space, a place which, for French philosopher Louis Marin (1984) for example, is 'the space that is neither yes nor no, true nor false $[. .$.$] a space of neutrality in which contradictions are$ allowed to play against one another rather than being resolved or indeed repressed' (Marin quoted in Maclaran and Brown 2005, 312). This is of course a particularly postmodern utopia, one which, in the words of Siebers 'critiques the concept of the self, questions community, unhinges cause and effect, and abhors explanation' (Siebers 1994, 31). Nevertheless, this utopian element links The Casting of Alexey to Transfiguration, which constitutes a visual representation / exploration of St. Petersburg, a place historically held in Russians' collective imagination to be 'an unreal city that was alien to Russia, a supernatural realm of fantasies and ghosts, a kingdom of oppression and apocalypse' (Figes 2002, 158).

If the spaces in which the heroes of Rubchinskiy's films evolve can be conceptualized as utopias, then the places he chooses to shoot his runway shows might be called heterotopias. A term first coined by Foucault (1967/2001; 2009), heterotopias are, in the words of Dominique Roux (in her study of that hyper-masculine space, the tattoo parlour), locations defined precisely in opposition to utopias. Unlike the latter, heterotopias are:

real places ... governed by rules that support various human imaginary projects. These include for example libraries as the purpose of accumulating all knowledge; asylums, prisons or nursing homes as ways to manage and correct physical or moral deviance; cinemas and theaters as spaces of creation of and projection into imagination; cemeteries as sites for commemoration and cult of the dead (Roux 2014, 64).

When it comes to organizing the 'imaginary projects' that are his runway shows, Rubchinskiy has a particular fondness for alternative, heterotopic spaces. This tendency can be seen in his early shows, such as The Empire of Evil. This show, his very first, featured archetypical Russian symbols, such as bears and Kalashnikovs, in what Rubchinskiy himself has more recently suggested was a response to the fear of Russia in the western press following the country's military conflict with neighbouring Georgia that summer (Kansara 2017). The heterotopic element is even more evident in his most recent shows. The Pitti Uomo show of June 2016 for example took place in the Manifattura Tabacchi, an abandoned cigarette factory built in Florence in the 1930s, at the height of Mussolini's fascism (Muret 2016). Rubchinskiy's next show was staged in 
Russia, or to be precise in the country's western enclave of Kaliningrad (a city described by Madsen, perhaps a little unfairly, as a 'ghost town' and a 'desolate backdrop': Madsen 2017a, 178-79). It took place in the 1875 hall of the former Köningsberg Stock Exchange, an imposing building designed in the Italian Renaissance style, which now serves as the city's Centre for Youth Culture. His most recent show to date at the time of writing (October 2017) was held in St. Petersburg, in a building that had previously housed a concert hall, library and theatre, and had also been home to the city's first rave, back in the 1990s (for a video of the show, see YouTube 2017). According to Cadogan and Hope Allwood (2017), during the show itself 'guests sat around a balcony, looking down on a set made up of smashed up theatre chairs, shrouded in smoke and lit up with the green lasers you will know if you've ever been to a techno rave.' This show coincided with the launch by INRUSSIA of a new collection of photographs, dedicated to the rave scene in St. Petersburg in the 1990s and explicitly conceived to complement it (Yurchak 2017). But the question is: what relevance might Foucault's concept, or indeed the use of heterotopic spaces have for Rubchinskiy's representation of extreme modes of masculinity?

A way to answer that question is suggested by Roux (2014). As she notes, quoting Foucault, heterotopias are 'various sites for exchanges, [in which] traditional rules currently applying to the marketplace are 'represented, contested and inverted' (Foucault, 1967/2001, p. 1574). Indeed, these places harbor transactions, which $[\ldots]$ are not based on common economic standards but on the restoration of alternative modes of exchange such as bartering, haggling, gift giving and/or reviving traditional ways of life.' In short, heterotopias constitute 'special places where deviant (re)presentations of aesthetics and relationships to the society are expressed' (Roux 2014, 63). Rubchinskiy has a long tradition of staging heterotopic runway shows, with his amateur models selected on social media, often wearing nothing more than customized t-shirts, and parading in specially converted public spaces. These are not the 'common economic standards' by which the runway show is conventionally organized, even by the most avant-garde, critical fashion designers operating today (Geczy and Karaminas 2017). Moreover, and more importantly, these in many respects 'deviant' representations of fashion also contain within them the kind of alternative mode of exchange which Roux sees as central to heterotopia; for in and around these runway shows, Rubchinskiy gives us time and time again the 'gift' of his (quite utopian) worldview, via the utopian bodies that circulate within them.

To understand the precise nature of this worldview, we need first to return to the heterotopia of Rubchinskiy's 2016 Pitti Uomo show. Rubchinskiy presented onlookers in Florence with a particular kind of extreme masculinity, one very different both from that on show in Transfiguration, and from that to be found in his recent lookbooks (Roberts 2017a). The Italian setting, the modernist architecture, the youthfulness and inexperience of his models, recruited via social media, as well as the clothes they wore such details as these all suggested unbridled, (not to say criminalized) male sexuality of the kind personified in and explored by the dedicatee of the show, Pier Paolo Pasolini. Indeed, as Muret puts it, referring specifically to Pasolini's work: 'Wearing sneakers, retro tracksuits and loose sweatshirts and chains on their necks, they were reminiscent of Pier Pasolini's [novel] "Ragazzi di vita" [1955], the rent boys plying their trade in Rome's suburbs described by the Italian poet, writer and director, who inspired the 
Russian designer for his Spring/Summer 2017 collection.' (Muret 2016). More than anything else, perhaps, it was the models' bodies, how those bodies moved and performed in space, that created this sense of a 'gang' of marginalized young men. The forty boys who made up the show, according to Muret 'looked all identical, with their close-cropped hair, athletic appearance and grumpy demeanour' (Muret 2016). This look, this body image, is described by Katerina Zolototrubova, fashion editor of Russian Vogue, as gopnik, a Russian term meaning 'the bad boys from the [Russian] suburbs' (Ferrier 2016). It is something that Rubchinskiy has long-since been developing, and something that sets him and his models apart in today's fashion world. As Petrarca has commented, in his Pitti Uomo show Rubchinskiy 'cast a crew of Soviet-looking teenage boys with bleached buzz cuts and without facial hair as the models. They were a sharp contrast to the usual Pitti peacocks' (Petrarca 2016: see Figure 4, below).

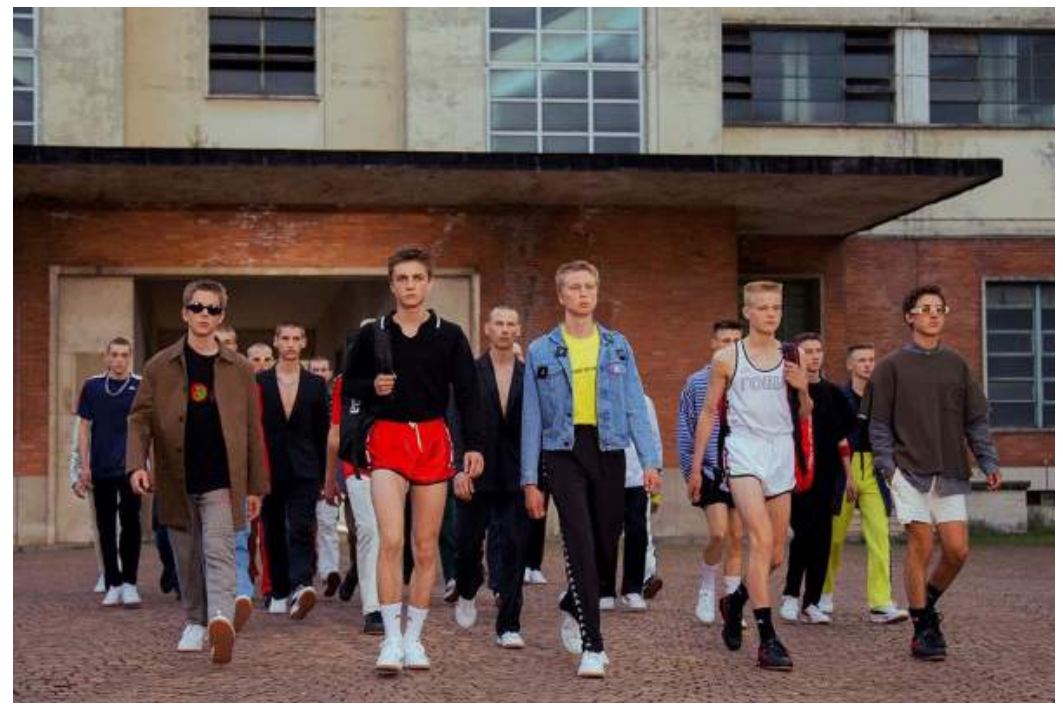

Fig. 4. Rubchinskiy's gang of 'bad boys from the suburbs' at the Pitti Uomo, June 2016 (source: Madsen 2017b).

Rubchinskiy's boys certainly exuded a raw, edgy masculinity during his Spring/Summer 2017 show in Florence, at odds with the kind of extrovert dandies - Petrarca's 'Pitti peacocks' - usually associated with this event (Leitch 2017). Rubchinskiy's staging of the bad-boy gopnik look, a look that is very different from that of his New Holland skaters in Transfiguration for example, but can in some ways be traced back to his 2008 Empire of Evil show, was given a new twist with his Kaliningrad show of January 2017. This show signalled a return to Russia for Rubchinskiy, and as such it held particular personal significance for the designer, who in an interview compared it explicitly to his Empire of Evil show held in Moscow in 2008 (Kansara 2017). Approximately one-third of the items of his Autumn/Winter 2017 show were football-themed garments made as part of a commercial collaboration with German brand Adidas, with a view to the 2018 FIFA 
World Cup, due to take place in Russia. Not insignificantly, the Kaliningrad show came just a few months after Russian football hooligans, dominated by right-wing nationalist militants, had made a name for themselves by running amok and fighting particularly viciously with rival fans during the UEFA European Championships in France. Whereas Rubchinskiy's show in 2008 featured elements - the bears and Kalashnikovs specifically designed to parody western views of Russia and Russian masculinity through caricature, his January 2017 show was on the contrary intended to be far less provocative. As he put it himself, more than a little euphemistically: 'It's interesting for me to show an image of a more modern Russian football fan' (quoted in Kansara 2017). The image of masculinity that Rubchinskiy displayed in Kaliningrad is very much a hybrid; during the show itself, the shaved heads, purposeful gazes and angular chins

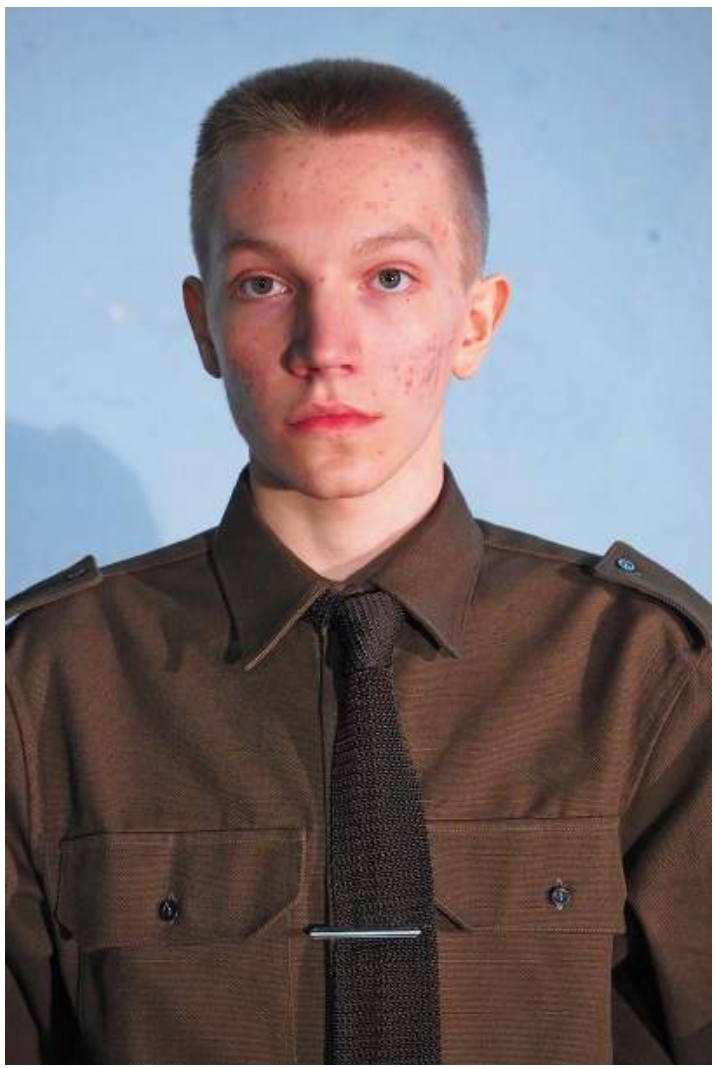
characteristic of Rubchinskiy's Pitti Uomo ' $\mathrm{g}$ a n g' m e m ber s combined with the acneridden cheeks and selfconscious postures of a number of his models at least one of whom was as young as 16 - to produce what one critic has called a 'poetic new masculinity' (Madsen 2017a, 172). Dressing up (literally) his 'poetic' vision in uniforms of extreme masculinity likely to intimidate many onlookers - the scarfbrandishing football hooligan, or brownshirted Fascist Youth League member, for example - only served to bring the 'poetic' element into sharper relief. The gopnik here has an angelic innocence almost unique to Rubchinskiy's models, who emerge very much as 'angels with dirty faces' (see for example Figure 5).

Fig. 5. Rubchinskiy's brown-shirted model from his January 2017 Kaliningrad show (source: Madsen 2017b).

A short video about the models featured in the show, produced by Rubchinskiy in collaboration with webzine and publisher INRUSSIA, was also issued (to view the video, 
entitled Apart, see Hsleh 2017). The video contains interviews with three of the young boys who answered Rubchinskiy's invitation posted on social media, and who converged on Kaliningrad from places as far away as Divnogorsk and Krasnodar ('just a regular town - nothing special about it', as one lad puts it), as well as from Kaliningrad itself (Hsleh 2017). In the video we follow them back home, walking their dogs, wandering around their city, or covering old abandoned buildings with graffiti. We also see them during rehearsals in the Centre of Youth Culture, where they appear (as one might expect, given their complete lack of professional experience) as self-conscious, naïve, and guileless. Seeing them being put through their paces by a particularly demanding choreographer, and observing one of them having his hair shaved off prior to the show, only accentuates the impression of watching raw recruits on their first day in the army. Nick Knight has argued that the new, digital medium of the fashion film breaks down the former barrier between the artist and the audience, exposing the creative process and thereby demystifying the fashioned object itself (Knight 2013; quoted in Geczy and Karaminas 2016, 117). While Knight is no doubt right, one might say that what is demystified here in this particular video is not so much the fashioned object, as the (masculine) subject as fashioned by Rubchinskiy. That subject emerges here as collectively exposed, fragile, and indeed vulnerable.

Demystification was also a key trope of Rubchinskiy's last runway show to date, staged in June 2017. To coincide with this show, Rubchinskiy also collaborated with INRUSSIA, this time on a collection of photographs of the (predominantly male) members of the St. Petersburg rave scene, taken in the 1990s (see Yurchak 2017). As Yurchak's introduction to the INRUSSIA collection makes abundantly clear, St. Petersburg's ravers in the anarchic 1990s in clubs such as Tunnel and 145 Fontanka were in many ways engaged in 'extreme' behaviour in 'extreme' times (for a fuller discussion of the rave scene in 1990s Russia, see Yurchak 1999). Paradoxically, however, what is most 'extreme' about the models in Rubchinskiy's 2017 shows, whether in St. Petersburg or in Kaliningrad, is their very ordinariness. This ordinariness is in sharp contrast with some of the clothes he designs, which one journalist has described as 'tricky, esoteric even: gently oversized utility jackets, high-waist jeans tied with shoelaces; T-shirts emblazoned with the hammer and sickle' (Ferrier 2016). This ordinariness, and the care Rubchinskiy takes, both in his photography and in his choreography, to present them as a 'gang,' a hodgepodge of street kids assembled from the four corners of the country (Lau 2016, Muret 2016, Dewintre 2017), symbolizes a rejection of the Russian glamour culture of the 2000s. Glamour is a new social structure many see as deliberately promulgated by Putin's regime, that has led to Russian men's collective 'disorientation and desperation' in the face of such 'radical transformation' (Goscilo and Strukov 2011, 12). In this way, Rubchinskiy and his models hark back not just to the pre-glamour, ravecrazy Russia of the 1990s, but way beyond that decade too.

Evans makes the point that so much of today's fashion involves a 'return of the repressed,' typical of many of today's fashion designers. As she cogently puts it, 'modern fashion gives us a collection of dislocated images in which many narratives, histories and images are condensed' (Evans 2013, 89), adding: 'the haunting of contemporary fashion design by images from the past is a kind of return of the repressed, in which shards of history work their way to the surface in new formations and are put to work as contemporary emblems' (Evans 2013, 95). The repressed returns quite spectacularly in 
Rubchinskiy's work in all sorts of guises and in all kinds of forms. Most obviously, perhaps, there are the Soviet emblems and slogans (which disappeared in the 1990s before being resurrected by Putin in the 2000s), with which Rubchinskiy likes to adorn his designs. More importantly, however, Rubchinskiy displays 'repressed' forms of masculinity. There is the un - indeed anti-glamorous - masculinity of the early postSoviet era, evident in his focus on the 1990s rave scene. Then there is the element of homoerotism and gender slippage, proscribed under the Soviets, that one finds in his some of his recent lookbooks (Roberts 2017a: see Figure 6). Finally, and perhaps most importantly, there are the gopniki of his latest runway shows.

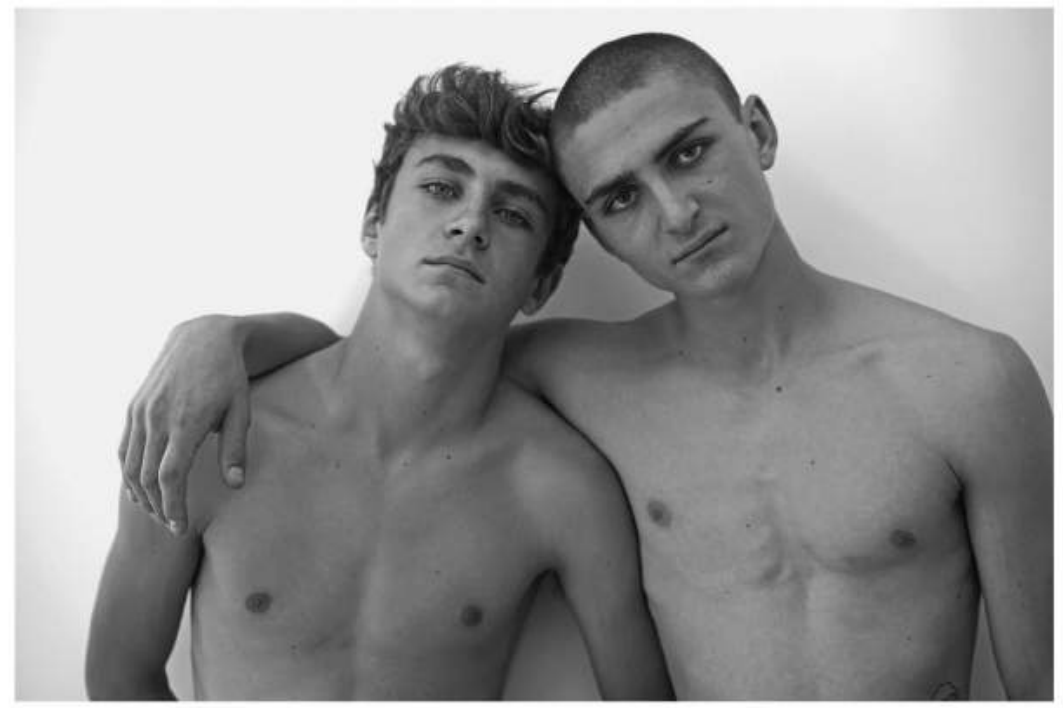

Fig. 6. An example of homoerotic masculinity in Rubchinskiy's Spring/Summer 2016 lookbook (source: Rubchinskiy [n. d. b]).

However, the different members of Rubchinskiy's 'gang of style' (Lau 2016) do not just embody the return of the repressed; they also stand for the utopian Russian body politic (Siebers 1994) as nostalgically imagined / envisioned by Rubchinskiy. The Apart video that coincided with the show held in January 2017 in Kaliningrad for example, is as much about the far-flung places the models come from, the geography and history of those places, as it is of the models themselves. Discussing that show (a Russian military enclave, taken from Nazi Germany at the end of WWII, and therefore hardly a politically neutral setting: Kansara 2017), Rubchinskiy opined: 'If you think about Russia you think about politics. It's more interesting for me to invite you here and show you what Russia is, rather than showing you in Paris' (Madsen 2017a, 178, emphasis mine). And for Rubchinskiy, 'showing [us] Russia' means first and foremost showing us its 
young men. This is what Kaliningrad purportedly allowed him to do, and what made it the perfect location for him. As he put it in an interview with Dazed magazine, 'to me, [Kaliningrad]'s like a portrait of Russia, an image of the youth generation of today' (quoted in Cadogan 2017). Rubchinskiy shows us Russia's (male) 'youth generation of today' in almost everything he does, whether it is filming skateboarders in St. Petersburg, photographing young kids in the Crimea in 2014, or dressing his catwalk models in t-shirts with Russkii Renessans - 'Russian Renaissance' - emblazoned on them, as he did at the Pitti Uomo in 2016. If his models all appear to be part of a gang perhaps even the ultimate fashion designer gang (Dewintre 2017) - the masculinity that gang now exudes is not one of 'bad boys' (Muret 2016). Rather it is one in which angels and demons cohabit in dialogic tension. The clothes may be oversized (Ferrier 2016), but if they are, this only serves to bring into greater relief how small these boys are. This was particularly evident in Rubchinskiy's Spring/Summer 2018 show, where the green lasers cut relentlessly, mercilessly through the models' semi-exposed bodies. As for the bodies themselves, they were clothed in garments of varying degrees of sportswear-ness (on account of the designer's continued collaboration with Adidas) that were either illfitting, or ill-suited to the spectacular context (a simulated rave). This tension between diametrically opposed modes of being - angelic innocence and something far darker that cohabit his models is ultimately what is most 'extreme' about the kind of masculinity Rubchinskiy presents us with, both here and elsewhere in his work. In short, the heterotopic spaces used by the designer for his recent runway shows all function as backcloths against which his utopian vision - both of Russian masculinity and of Russia itself - stands out in stark relief.

\section{Conclusion}

In an article on the legacy of British fashion designer Alexander McQueen - and in particular on his final show, entitled Angels and Demons - Nathalie Khan discusses fashion as 'mythology' (Khan 2013). Gosha Rubchinskiy's work, both his fashion and his image making more generally, is full of mythology, in particular surrounding masculinity, Russian masculinity and Russian identity. In an unconscious echo of McQueen, that identity is one which oscillates between the two extremes of angel and demon. In conclusion, then, these spaces - both the New Holland skateboard park and the spaces staging his runway shows, whether in Russia or abroad - serve as the (quite remarkable) backdrop against which Rubchinskiy constructs his artistic and ideological project. This project involves giving us the 'gift' of his very personal, deeply nostalgic and ultimately 'glocal' vision of Russia, a vision in which his country exists in a quite specific chronotope, one which is both here and there, now and then, heterotopia and utopia. His male models play a central role in expressing this vision, since in a long-established Russian tradition (Haynes 2003), they stand both metaphorically and metonymically for the (Russian) body politic.

Gosha Rubchinskiy is not just a highly successful international menswear brand. He is also an artist steeped in a very specifically Russian tradition. That tradition is one in which the artist has a mission salvatrice, a duty to use beauty to explore Russia's identity and place in the world. As Rubchinskiy put it in an interview with $i$-D's Anders Christian Madsen (Madsen 2017a: 179), comparing himself to Pasolini in the process: '[n my runway shows] I ask, what is Europe now? What is Italy now? What is Russia now?' (In 
this respect, it is surely no coincidence that Rubchinskiy returns time and again to the youths of St. Petersburg, that 'artificial' city built to be Peter the Great's 'window on the West,' and for so long the focal point of so much debate in Russian intellectual and cultural circles on the country's identity and direction: Volkov 1995). Revisiting, and at times Russifying, major western fashion brands such as Fila, Tommy Hilfiger (reproduced on a t-shirt mixed with the Russian and Chinese flags) and Adidas, Rubchinskiy has a very 'glocal' view, not just of his own brand, but of Russia itself. It is primarily through the male subjects and their performances of a range of extreme forms of masculinity that we see in his films, his photography and his fashion work, that this view is expressed.

Rubchinskiy demonstrates via the range of extreme masculinities alluded to in his work both a concern with (Russian) national identity, and an insistence on Russia's cultural ambivalence straddling East and West. As he put it, in a comment about Kaliningrad but which could be taken to apply to Russia as a whole: 'It's Russia and it's a small city, but at the same time it's in the middle of Europe' (quoted in Kansara 2017). This search for Russia's national identity, and the concomitant insistence on the country's geographical and cultural ambivalence, is the Russian Idea that has preoccupied Russian artists for centuries (Beumers 1999, Franklin and Widdis 2004). If Rubchinskiy denies his work has a political agenda (see for example Madsen 2017a), this is because in Russian culture, asking questions such as these is not seen as political, but rather as something far more normal - the very opposite of 'extreme.' These questions are moreover particularly pertinent in today's post-Soviet era. Answering them is at the heart of the 'informational war' Rubchinskiy is engaged in and to which he so tellingly referred during his interview with SHOWstudio's Lou Stoppard in 2015. This is the significance of the binary oppositions running through all his work, between east and west (in his fashion designs), and between angel and gopnik (in his photography and video work). Rubchinskiy is one of the very first artists to explore Russian identity by looking nostalgically back to the post-Soviet era (the 1990s of his childhood and early adolescence: Madsen 2017a). This fact alone makes him worthy of note. That he should choose to do so via the prism of masculinity is in itself nothing new, given what Evans Clements (2002) notes about the historical connection between the question 'what is Russia?' and 'how should Russian men behave?' On the other hand, that he should so radically challenge the norms of masculine beauty and indeed masculinity that have emerged in Putin's Russia - and 'trailblazing a new poetic masculinity' (Madsen 2017a, 172 ) in the process - is surely the most interesting and innovative thing about him although it is unlikely the world's fashion cognoscenti will choose to focus on this aspect of his work.

Amico, Stephen. 2014. Roll Over, Tchaikovsky! Russian Popular Music and Post-Soviet Homosexuality. Urbana: University of Illinois Press.

Anon. 2017. "La Goshattitiude." Vogue Hommes 25: 84.

Baker, Harriet. 2014. "Exclusive: Gosha Rubchinskiy's Crimea/Kids." AnOther, September 1. Accessed May 12, 2017. http://www.anothermag.com/artphotography/3863/exclusive-gosha-rubchinskiys-crimea-kids. 
Bakhtin, Mikhail M. 1968. Rabelais and His World. Translated by Hélène Iswolsky. Cambridge, MA: MIT Press.

Bakhtin, Mikhail M. 1981. The Dialogic Imagination: Four Essays. Edited by Michael Holquist. Translated by Caryl Emerson and Michael Holquist. Austin: University of Texas Press.

Barthes, Roland. 1973. Mythologies. Translated by Annette Lavers. London: Paladin Books.

Bauman, Zygmunt. 2007. Consuming Life. Cambridge: Polity.

Belk, Russell W. 1988. "Possessions and the Extended Self." Fournal of Consumer Research 15(2): 139-68. doi: 10.1086/209154

Beumers, Birgit. 1999. "Introduction." In Russia on Reels: The Russian Idea in Post-Soviet Cinema, edited by Birgit Beumers, 1-11. London and New York: I. B. Tauris.

Brown, Stephen. 1988. Postmodern Marketing Two: Telling Tales. London: International Thompson Business Press.

Gadogan, Dominic. 2017. "Gosha Rubchinskiy is Showing in Russia Again." Dazed [n. d.]. Accessed June 20, 2017. http://www.dazeddigital.com/fashion/article/ 35726/1/gosha-rubchinskiy-st-petersburg-show-ss 18 .

Gadogan, Dominic, and Emma Hope Allwood. 2017. "Gosha's SS18 Show: Burberry, Russian Rave and a New Zine." Dazed [n. d.]. Accessed June 20, 2017. http://www.dazeddigital.com/fashion/article/36280/1/gosharubchinskiy-ss 18-show-burberry-russia-rave-zine-adidas.

Debray, Régis. 1992. Vie et Mort de l'Image: Une Histoire du Regard en Occident. Paris: Gallimard.

Dewintre, Hervé. 2017. "Le Gang Règne sur les Catwalks. [The Gang Rules on the Catwalks]." L'Officiel Hommes 47: 72-75.

Evans, Caroline. 2013. "Yesterday's Emblems and Tomorrow's Commodities: The Return of the Repressed in Fashion Imagery Today." In Fashion Cultures Revisited, edited by Stella Bruzzi and Pamela Church Gibson, 77-102. Abingdon and New York: Routledge.

Evans Clements, Barbara. 2002. "Introduction." In Russian Masculinities in History and Culture, edited by Barbara Evans Clements, Rebecca Friedman and Dan Healey, 1-14. Basingstoke: Palgrave Macmillan.

Fearon, Faye (2017). "First Look: Gosha Rubchinskiy's AW17 Lookbook." Dazed [n. d.]. Accessed June 20, 2017. http://www.dazeddigital.com/fashion/article/ 36351/1/first-look-gosha-rubchinskiys-aw17-lookbook.

Ferrier, Morwenna. 2016. "The Man Who Made Russian Fashion Cool." The Guardian, October 12. Accessed March 22, 2017. https:// www.theguardian.com/fashion/2016/oct/12/russian-fashion-gosharubchinskiy-post-soviet-designer-menswear.

Figes, Orlando. 2002. Natasha's Dance: A Cultural History of Russia. London: Allen Lane.

Foucault, Michel. (1967/2001) "Des Espaces Autres." In Michel Foucault (ed.) Dits et Ecrits 1954-1988 II, 1976-1988, edited by Michel Foucault, 1571-81. Paris: Gallimard. ["Of Other Spaces: Utopias and Heterotopias." Translated by Jay Miskowiec. Accessed October 3, 2017. http://web.mit.edu/allanmc/www/ foucault1.pdf]

Foucault, Michel. 2009. Le Corps Utopique suivi de Les Hétérotopies. Paris: Editions Lignes. ["The Utopian Body." In Sensorium. Embodied Experience, Technology, and 
Contemporary Art, edited by Caroline Jones, 229-34. Translated by Lucia Allais. Cambridge, MA: The MIT Press.]

Fox, Imogen. 2016. "Vetements' Lotta Volkova: 'Conventionally Beautiful Things Are...Boring." The Guardian, September 17. Accessed April 11, 2017. https:// www.theguardian.com/fashion/2016/sep/17/vetements-stylist-lotta-volkova.

Franklin, Simon, and Emma Widdis. 2004. "Preface." In National Identity in Russian Culture: An Introduction, edited by edited by Simon Franklin and Emma Widdis, xi-xii. Cambridge: Cambridge University Press.

Fury, Alexander. 2016. "For Gosha Rubchinskiy, Sweatshirts, T-Shirts, and Jeans Are the Coolest Things in Fashion." W, September 29. Accessed March 22, 2017. http://www.wmagazine.com/story/for-gosha-rubchinskiy-sweatshirts-t-shirtsand-jeans-are-the-coolest-things-in-fashion.

Geczy, Adam and Vicki Karaminas. 2017. Critical Fashion Practice: From Westwood to Van Beirendonck. London and New York: Bloomsbury Academic.

Gorham, Michael S. 2013. "Putin's Language." In Putin as Celebrity and Cultural Icon, edited by Helena Goscilo, 82-103. Abingdon and New York: Routledge.

Goscilo, Helena. 2013. "Putin's Performance of Masculinity: The Action Hero and Macho Sex-Object." In Putin as Celebrity and Cultural Icon, edited by Helena Goscilo, 180-207. Abingdon and New York: Routledge.

Goscilo, Helena, and Vlad Strukov. 2011. "Introduction." In Celebrity and Glamour in Contemporary Russia: Shocking Chic, edited by Helena Goscilo and Vlad Strukov, 1-26. Abingdon and New York: Routledge.

Haynes, John. 2003. New Soviet Man: Gender and Masculinity in Stalinist Soviet Cinema. Manchester and New York: Manchester University Press.

Healey, Dan. 2010. "Active, Passive, and Russian: The National Idea in Gay Men's Pornography." The Russian Review 69(2): 210-30. doi: 10.1111/j. 1467-9434.2010.00563.x

Hsleh, Vanessa. 2017. "Watch This Doc About the Models of Gosha's Kaliningrad Show." Dazed [n. d.]. Accessed June 22, 2017. http://www.dazeddigital.com/ fashion/article/35023/1/watch-this-doc-about-the-models-of-gosharubchinskiys-kaliningrad-show.

ICA. 2014. "Culture Now: Gosha Rubchinskiy." August 29. Accessed March 22, 2017. https://www.ica.art/whats-on/culture-now-gosha-rubchinskiy.

Jefferson, Ann. 1989. "Bodymatters: Self and Other in Bakhtin, Sartre and Barthes." In Bakhtin and Cultural Theory, edited by Ken Hirschkop and David Shepherd, 152-77. Manchester and New York: Manchester University Press.

Kansara, Vikram Alexei. 2017. "How Gosha Rubchinskiy and Adidas Are Refashioning Football." Business of Fashion, January 12. Accessed May 12, 2017. https://www.businessoffashion.com/articles/bof-exclusive/gosha-rubchinskiyadidas-kaliningrad-globalization-localization.

Kansara, Vikram Alexei, and Anastasiia Fedorova. 2016. "How Comme des Garçons Grew Gosha Rubchinskiy." Business of Fashion, March 17. Accessed March 22, 2017. https://www.businessoffashion.com/articles/bof-exclusive/ comme-des-garcons-gosha-rubchinskiy-dover-street-market-london.

Karaminas, Vicki. 2012. "Image: Fashionscapes - Notes Toward an Understanding of Media Technologies and Their Impact on Contemporary Fashion Imagery." 
In Fashion and Art, edited by Adam Geczy and Vicki Karaminas, 177-87. London and New York: Bloomsbury Academic.

Khan, Nathalie. 2012. "Stealing The Moment: The Non-narrative Fashion Films of Ruth Hogben and Gareth Pugh.” Film, Fashion and Consumption 1(3): 251-62. doi: 10.1386/ffc.1.3.251_1

Khan, Nathalie. 2013. "Fashion as Mythology: Considering the Legacy of Alexander McQueen." In Fashion Cultures Revisited, edited by Stella Bruzzi and Pamela Church Gibson, 261-69. Abingdon and New York: Routledge.

Knight, Nick. 2013. "SHOWstudio: Thoughts on Fashion Film.” Accessed March 24, 2017. https://www.youtube.com/watch?v=BOBZMS9Bhr0.

Kon, Igor'. 2003. Muzhskoe telo $v$ istorii kul'tury [The Male Body in the History of Culture] Moscow: Slovo.

Kuldova, Tereza. 2016. Luxury Indian Fashion: A Social Critique. London and New York: Bloomsbury Academic.

Lau, Susanna. 2016. "Gangs of Style: Decoding Pitti Uomo." AnOther, June 20, Accessed June 22, 2017. http://www.anothermag.com/fashion-beauty/8786/ gangs-of-style-decoding-pitti-uomo.

Leitch, Luke. 2017. "Dandyland." 1843 (April/May): 48-51.

Levant, Roland F. et al. 2003. "Masculinity Ideology among Russian and U.S. Young Men and Women and Its Relationship to Unhealthy Lifestyle Habits among Young Russian Men." Psychology of Men and Masculinity 4(1): 26-36. doi: 10.1037/1524-9220.4.1.26

Maclaran, Pauline, and Stephen Brown. 2005. "The Center Cannot Hold: Consuming the Utopian Marketplace." Fournal of Consumer Research 32(2): 311-23. doi: 10.1086/432240

Madsen, Anders Christian. 2017a. "From Gosha with Love." i-D 347: 170-79.

Madsen, Anders Christian. 2017b. "From Russia with Love: We Meet Gosha Rubchinskiy and His Gang." i-D, March 27. Accessed October 3, 2017. https://i-d.vice.com/en_uk/article/j5mxwp/from-russia-with-love-we-meetgosha-rubchinskiy-and-his-gang.

Marin, Louis. 1984. Utopics: The Semiological Play of Textual Spaces. Translated by Robert A. Vollrath. Atlantic Highlands: Humanities Press.

Massoca, Fabrizio. 2016. "Le New Black. [The New Black]." L'Officiel Hommes 44: 40-41.

Muret, Dominique. 2016. "Gosha Rubchinskiy Takes His Bad Boys' Gang to Pitti Uomo.” Fashion Network, June 16. Accessed March, 27 2017. http:// se.fashionnetwork.com/news/Gosha-Rubchinskiy-takes-his-bad-boys-gang-toPitti-Uomo, 704123.html\#.WNi-4mU02b9.

Petrarca, Emilia. 2016. “Gosha's Gang: A Who's Who of the Designer's Inner Circle." W, June 15. Accessed June 22, 2017. https://www.wmagazine.com/ gallery/gosha-rubchinskiy-spring-2017-pitti-uomo/all.

Roberts, Graham H. 2017a. "Homo Post-sovieticus: (Re)fashioning the Male Body in the New Russia." Journal of Asia-Pacific Pop Culture 2(1): 6-29. doi: 10.5325/ jasiapacipopcult.2.1.0006

Roberts, Graham H. 2017b. "Leader of the Gang: Gosha Rubchinskiy and the Death of the Catwalk." Fashion Theory: The Fournal of Dress, Body and Culture 21(6): 689-707. doi: 10.1080/1362704X.2017.1335998 
Roux, Dominique. 2014. "Revisiting (Not So) Commonplace Ideas About the Body: Topia, Utopia and Heterotopia in the World of Tattooing." In Research in Consumer Behaviour 16, edited by John W. Schouten, Diane M. Martin and Russell Belk, 59-80. Bingley: Emerald Group Publishing.

Roxburgh, Angus. 2012. The Strongman: Vladimir Putin and the Struggle for Russia London and New York: I. B. Tauris.

Rubchinskiy, Gosha. [n. d. a] "Video." Accessed March 24, 2017. www.gosharubchinskiy/video.

Rubchinskiy, Gosha. [n. d. b] "Collection." Accessed October 5, 2017. http:// gosharubchinskiy.com/collection/ss2016/

Rubchinkiy, Gosha. 2012. Preobrazhenie [Transfiguration] London: IDEA Books.

SHOWstudio. [n. d.]. "Mad About The Boy." Accessed March 22, 2017. http:// showstudio.com/project/mad about the boy.

Siebers, Tobin. 1994. "Introduction: What Does Postmodern Want? Utopia." In Heterotopia: Postmodern Utopia and the Body Politic, edited by Tobin Siebers, 1-39. Ann Arbor: The University of Michigan Press.

Stoppard, Lou. 2015. "Lou Stoppard Reports on the Gosha Rubchinskiy Show." SHOWstudio, June 25. Accessed March 22, 2017. http://showstudio.com/ collection/gosha rubchinskiy_paris_menswear_s_s_2016/ lou stoppard reports on the gosha rubchinskiy show.

Sperling, Valerie. 2015. Sex, Politics, and Putin: Political Legitimacy in Russia. Oxford and New York: Oxford University Press.

Suliman, Ali. 2015. "9 Things We Learned About Gosha Rubchinskiy From His First Video Interview." The Fader, October 29. Accessed March 24, 2017. http:// www.thefader.com/2015/10/29/gosha-rubchinskiy-interview-showstudio.

Varese, Federico. 2001. The Russian Mafia: Private Protection in a New Market Economy. Oxford and New York: Oxford University Press.

Volkov, Solomon. 1995. St. Petersburg: A Cultural History. New York: The Free Press.

YouTube. 2008. "Gosha Rubchinskiy. Imperiya Zla (pokaz). [Gosha Rubchinskiy. Empire of Evil (show)."] Accessed March 22, 2017. https:// www.youtube.com/watch?v=3LqZADqxpvs.

YouTube. 2015. "Gosha Rubchinskiy. In Fashion Interview, Uncut Footage." Accessed March 24, 2017. https://www.youtube.com/watch?v=EFW4y5Iyh Q.

YouTube. 2017. "Gosha Rubchinskiy 2018 Spring/Summer Collection." Accessed June 23, 2017. https://www.youtube.com/watch?v=KKmAIc3N6T8.

Yurchak, Alexei. 1999. "Gagarin and the Rave Kids: Transforming Power, Identity, and Aesthetics in Post-Soviet Nightlife." In Consuming Russia: Popular Culture, Sex, and Society since Gorbachev, edited by Adele Marie Barker, 76-109. Durham, NC and London: Duke University Press.

Yurchak, Alexei. 2017. "The Rise of the St. Petersburg Rave." INRUSSIA [n. d.], Accessed June 22, 2017. http://inrussia.com/the-rise-of-the-st-petersburgrave.

Graham H. Roberts is Associate Professor of Russian Studies at Nanterre University, near Paris and member of the CRPM research group. He recently published a monograph entitled Consumer Culture, Branding and Identity in the New Russia: From Five-Pear Plan to $4 \times 4$ (Routledge, 2016), and edited a volume on material culture in Russia and the 
USSR (Bloomsbury Academic, 2017). A member of the Extreme Anthropology Network, his current research interests include men's fashion brands and branding strategies, the politics of fashion in emerging economies, and the representation of masculinity in advertising. 